Abstracta Iranica Abstracta Iranica

Revue bibliographique pour le domaine irano-aryen

Volume 27 | 2006

Comptes rendus des publications de 2004

\title{
" Astral symbology on Iranian coinage ». East and West, 54, 1-4 (December 2004), pp. 31-53, 20 figs.
}

\section{Karin Mosig-Walburg}

\section{(2) OpenEdition}

1 Journals

\section{Édition électronique}

URL : http://journals.openedition.org/abstractairanica/5807

DOI : 10.4000/abstractairanica.5807

ISSN : 1961-960X

Éditeur :

CNRS (UMR 7528 Mondes iraniens et indiens), Éditions de l'IFRI

\section{Édition imprimée}

Date de publication : 15 mai 2006

ISSN : 0240-8910

\section{Référence électronique}

Karin Mosig-Walburg, « «Astral symbology on Iranian coinage ». East and West, 54, 1-4 (December 2004), pp. 31-53, 20 figs. », Abstracta Iranica [En ligne], Volume 27 | 2006, document 119, mis en ligne le 02 janvier 2007, consulté le 25 septembre 2020. URL : http://journals.openedition.org/ abstractairanica/5807 ; DOI : https://doi.org/10.4000/abstractairanica.5807

Ce document a été généré automatiquement le 25 septembre 2020.

Tous droits réservés 


\title{
« Astral symbology on Iranian coinage ». East and West, 54, 1-4 (December 2004), pp. 31-53, 20 figs.
}

\author{
Karin Mosig-Walburg
}

1 D'après A.G. la véritable signification des symboles astraux sur les monnaies iraniennes n'a pas été suffisamment soulignée dans la littérature numismatique. Il esquisse l'usage de ces symboles sur les monnaies des Parthes, des rois en Perside et des Sassanides et, renvoyant aussi aux monnaies byzantines, il propose d'interpréter ces symboles comme un renvoi au souverain kosmokrator. Ce serait l'usage des symboles astraux sur les monnaies sassanides qui aurait donné l'exemple pour les monnaies byzantines (folles) de l'empereur Anastasius. A.G. donne encore d'autres exemples qui montrent d'après lui une influence mutuelle entre les deux puissances sur le plan numismatique, p. ex. le poids du dinar sassanide qui aurait suivi l'exemple romain. Tandis que la dernière supposition est douteuse, celle d'une influence sassanide sur le monnayage byzantin en ce qui concerne l'usage des symboles astraux est à rejeter absolument. C'est déjà sur les monnaies de l'empereur Arcadius (395-408) qu'une étoile apparaît derrière le buste de l'empereur et sur le revers de diverses monnaies romaines de la première partie du $4^{\mathrm{e}} \mathrm{s}$. des symboles astraux sont présents comme éléments constitutifs de l'iconographie.

\section{INDEX}

Thèmes : 3.2.2. Pré-Achéménides et Achéménides 


\section{AUTEURS}

KARIN MOSIG-WALBURG

Université de Francfort 